\title{
Donald A.B. Lindberg: Uomo Universal
}

\author{
Kelly McGEE ${ }^{1}$ \\ Pullman, WA. U.S.A.
}

Keywords: Donald A. B. Lindberg, M.D., Lindberg family history

I am admiring a photo Dr. Lindberg took years ago of the wet bricks of the patio at his home in Missouri. Don and Mary built the house, and he laid each of the individual bricks. You can feel the chill in the air and see the sun's rays melt the snow. The photograph connects your senses and feelings as he experienced them.

Don loved all forms of art and incorporated them into his scientific work and initiatives. Don could design a house and pioneer medical computing, each with confidence and success. He could accomplish anything to which he committed time and energy, and he never stopped learning. Indeed, my father-in-law influenced me to achieve, persevere, and never be afraid of new experiences.

When visiting the Lindbergs' home in Maryland, I looked forward to walking the halls and enjoying Don's photographs. He documented his admiration for his family, travel, and everyday objects with a unique perspective.

Yet, the most comforting part of a visit was knowing you would find Don sitting in his chair reading. There was an endless stack of newspapers, books, journals, magazines, and maps. He was interested in many subjects and he continued to study and effortlessly share his knowledge - all within the warmth of the family room.

Later, Don graciously took my family on cultural outings throughout the greater Washington area. We gratefully saw Renoir's 'Luncheon of the Boating Party,' heard Mozart's 'The Marriage of Figaro,' and dined at a social club in the presence of Nobel Prize winners.

Overall, Don was a person of his time. He stayed up to date with current events as well as trends in literature and arts. He displayed expertise in cultural history and politics. Don's example prompted me to take time every morning and evening to read and stretch my scope of knowledge and insight. He demonstrated the more you read, more events seemed connected, if not universal.

My fondest memory was attending a biomedical informatics course with Don and his family at Woods Hole, Massachusetts. While we were there, I began to understand Don's commitment better to delivering health information to providers, patients, and the public, as well as train the next generation of health informatics specialists. He lived to share knowledge with others.

During one Woods Hole day, Don joined his family on a squid collection boat after class. It was fascinating to watch him communicate with the captain and other locals on the crew. Following the boat ride, Don immersed himself in the seaside community by talking to patrons at Captain Kidd, a local tavern.

Don's competence and knowledge often made him one with whomever he conversed. Also, just by being with him at Woods Hole, I was introduced to the

\footnotetext{
${ }^{1}$ Corresponding author: kelly.mariej@gmail.com
} 
importance of healthcare technology, the steps to building a wooden sailboat, and how to value others.

In July 2012, my family received a collection of Don's photographs, 'Where Is Fancy Bred.' The title was intriguing and sparked my curiosity to study each photo and read his passages. The majority of the pictures depicted his love for water, the most vital element in the universe. The images reminded me of these verses in the Tao Te Ching:

His heart is kind like water that benefits all.

His words are sincere like the constant flow of water

His governing is natural without desire which is like the softness of water that penetrates through hard rock.

As I perused the book, I realized that Don saw unlimited potential in all living things, which influenced his life purpose. He was a gentleman with a firm handle on understanding himself and the world around him.

Don, thank you for being a Captain in the vast waters of science, literature, history, art and for believing in me. 